\title{
Badan Hukum di Langit Pendidikan (Studi Evaluasi Kebutuhan Satuan Pendidikan)
}

\author{
M. Kholid Fathoni \\ Email: Izdiharbabelan@hotmail.com
}

\begin{abstract}
Abstrak: Ketentuan tentang keharusan penyelenggara dan/atau satuan pendidikan berbentuk badan hukum pendidikan masih merupakan agenda hukum negeri ini. Pasal 53 UU Sisdiknas No.20/2003 mengamanatkan disusunnya suatu undang-undang tentang badan hukum pendidikan. Sebelumnya, UU No 9/2003 Tentang Badan Hukum Pendidikan sudah diterbitkan, namun oleh Mahkamah Konstitusi dinyatakan "tidak mengikat" pada tangal 31 Maret 2010. Apabila "undang-undang baru" akan disusun menggantikan UU No 9, maka diperlukan upaya Pemerintah agar benar-benar memperhatikan poin-poin penting penyebab pembatalan UU No 9 serta suara masyarakat secara lebih luas agar kelak tidak mengalami nasib UU No 9. Dengan cara melakukan analisis terhadap dokumen di berbagai forum pembahasan seputar permasalahan, penelitian ini dimaksudkan memetakan permasalahan badan hukum di bidang pendidikan. Penelitian ini dapat dimanfaatkan untuk membantu para pengambil kebijakan pendidikan mengetahui kebutuhan nyata para penyelenggara pendidikan di lapangan.
\end{abstract}

Kata kunci: Otonomi pengelolaan pendidikan, badan hukum, penyelenggara pendidikan, dan satuan pendidikan.

\begin{abstract}
The obligation of legal body upon every educational institution or its founder is still an unfinished law agenda of this country. Act No 20/2003 on National Education stated that the specific law on education legal body must be enacted. The government has released the law No 9/2009 about Legal Body of School and University, but the Council of Constitution has canceled it in 2010. If a new regulation on legal body will be initiated as law, instead of the cancelled one, the Government should be in alert and in full contemplation among critics, last mistakes, and wider community sounds so that can avoid obstacles. This research is important in accordance with Governmental planning when the body of education institution will be constructed as a legal entity. The sounds and documents which are collected from various forums in discussion of the topic will be analyzed as a research conclusion.
\end{abstract}

Key words: Educational Autonomy, legal body, institutional founder in education, school and university.

\section{Pendahuluan}

Keinginan untuk mempercepat peningkatan mutu pendidikan di Indonesia dapat ditempuh melalui penguatan "status hukum satuan pendidikan". Selama ini, status hukum satuan pendidikan banyak menggunakan "baju hukum" penyelenggaranya. Misalnya sekolah dasar (SD) berada di bawah payung hukum yayasan tertentu (di bawah UU Yayasan) yang menyelenggarakannya. Bernaung di bawah badan hukum lain terkadang ada dampak negatifnya, di mana kewenangan satuan pendidikan dalam urusan pendidikan menjadi lemah ketika berhadapan dengan kewenangan yayasan. Padahal satuan pendidikan merupakan lembaga inti pelaksana program pendidikan.

Gagasan menjadikan satuan pendidikan berbadan hukum sendiri merupakan upaya memperkuat status hukum satuan pendidikan dengan tujuan menjadikannya lebih mandiri dan otonom. Dalam Penjelasan Umum Undang-Undang No 20/2003 tentang Sistem Pendidikan Nasional disebutkan bahwa pendidikan nasional mempunyai visi terwujudnya sistem pendidikan sebagai pranata sosial yang kuat dan berwibawa untuk memberdayakan semua warga negara Indonesia berkembang menjadi manusia yang berkualitas sehingga mampu dan proaktif menjawab 
tantangan zaman yang selalu berubah. Dengan menjadi badan hukum, maka satuan pendidikan akan memiliki hak dan kewajiban seperti entitas tersendiri yang bisa bertindak sepenuhnya, dan otomatis bisa lebih mandiri. Status badan hukum bagi satuan pendidikan sebenarnya sudah dirintis sejak pemberlakuan BHMN (Badan Hukum Milik Negara) pada beberapa perguruan tinggi negeri di tahun 2000 sampai dengan tahun2010 secara bertahap. Perguruan tinggi dimaksud yaitu Universitas Indonesia (UI), Universitas Gajah Mada (UGM), Institut Teknologi Bandung (ITB), Institut Pertanian Bogor (IPB), Universitas Sumatera Utara (USU), Universitas Pendidikan Indonesia (UPI), Universitas Airlangga (UNAIR), dan Universitas Pertahanan (UNHAN).

Pada perkembangannya, UU Sisdiknas No 20/ 2003 memberlakukan kewajiban bentuk badan hukum ini bagi seluruh penyelenggara dan/atau satuan pendidikan, baik pada jenjang dasar, menengah, maupun tinggi. UU Sisdiknas No 20/ 2003 mengamanatkan penyusunan UU tentang Badan Hukum Pendidikan yang disyahkan oleh DPR RI menjadi UU No 9 tahun 2009 tentang Badan Hukum Pendidikan. Namun, yang akhirnya dibatalkan oleh Mahkamah Konstitusi pada tahun 2010. Cukup mengagetkan karena UU No 9 terhitung masih berumur jagung dan nyaris belum sempat diimplementasikan.

Sementara itu, Pasal 53 UU No 20/2003 tentang Sistem Pendidikan Nasional, yang menjadi dasar penyusunan UU No 9 itu sendiri sampai saat ini tidak dibatalkan. Ini artinya, Pemerintah bersama DPR RI masih berkewajiban untuk menyusun kembali UU pengganti (UU baru) tentang badan hukum pendidikan. Dalam amar keputusan Mahkamah Konstitusi, terdapat pesan konstitusional agar badan hukum pendidikan diubah dari yang semula berupa "bentuk badan hukum tertentu", menjadi "fungsi" badan hukum pendidikan. Dalam kerangka itu, Pemerintah bersama DPR harus berupaya menterjemahkan keputusan Mahkamah Konstitusi perihal fungsi badan hukum pendidikan.

Studi evaluasi ini menganalisis sejumlah dokumen mengenai upaya tersebut, termasuk di dalamnya rangkuman dialog yang diselenggarakan oleh Balitbang Kemendiknas bersama para pemangku kepentingan, yang kesemuanya mencerminkan arus komunikasi intensif antara Pemerintah dengan para pihak, terutama pakar pendidikan dan penyelenggara/pengelola pendidikan.

Permasalahan satuan pendidikan ketika diharuskan berbentuk badan hukum pendidikan bersumber dari adanya ketimpangan komunikasi atau konsep dalam menterjemahkan kebutuhan para praktisi pendidikan terhadap makna otonomi pengelolaan satuan pendidikan dalam bentuk/ fungsi badan hukum pendidikan di Indonesia. Dalam kerangka ini penelitian diharapkan menemukan jawaban atas pertanyaan: "Apakah sesungguhnya para penyelenggara dan pengeIola satuan pendidikan membutuhkan otonomi pengelolaan pendidikan hingga dalam bentuk/ fungsi badan hukum pendidikan?"

Studi evaluasi ini bertujuan untuk mengevaluasi apakah masyarakat penyelenggara dan pengelola satuan pendidikan sesungguhnya membutuhkan otonomi hingga tingkat aturan yang berciri badan hukum pendidikan. Selain perlu untuk memberikan sumbangan pemikiran kepada negara, tulisan ini bisa menjadi khazanah pengetahuan empiris serta dokumentasi, terkait dengan permasalahan otonomi pengelolaan pendidikan dan badan hukum pendidikan di Indonesia.

\section{Kajian Literatur Badan hukum dan otonomi manajemen pendidikan}

Definisi badan hukum (rechtpersoon atau body corporate), seperti diungkapkan R. Subekti (1979), pada pokoknya adalah suatu badan atau perkumpulan yang dapat memiliki hak-hak dan melakukan perbuatan seperti manusia, serta memiliki kekayaan sendiri, dapat menggugat atau digugat di depan hukum. Penjelasan H.Th. Ch. Kal dan V.F.M. Den Hartog (dalam Chidir Ali, 1999, Badan Hukum, hal. 19) mengukuhkan bahwa manusia sejatinya adalah suyek hukum. Tetapi ada juga subyek hukum yang merupakan suatu organisasi, yakni badan hukum. Karenanya M. Marwan dan Jimmy mencirikan badan hukum sebagai organisasi, perkumpulan atau yang lainnya, yang dilakukan dengan akte otentik, dan oleh hukum diperlakukannya sebagai persona atau sebagai orang (M. Marwan dan Jimmy, 2009). 
Di dalam penjelasan mengenai manusia sebagai subyek hukum dinyatakan bahwa manusia harus berkepribadian hukum. Ini disebabkan karena manusia ada yang tidak berkepribadian hukum, bahkan menjadi obyek hukum, misalnya manusia yang berkedudukan sebagai budak (slaven). Budak tidak memiliki hakhak manusia sebagaimana mestinya. Karenanya Deklarasi tentang Human of Rights menegaskan kembali kedudukan manusia sebagai suyek hukum dengan melarang perbudakan. Senada dengan ini, UUDS-RI 1950 Pasal 10 pernah menegaskan bahwa "Tiada seorangpun boleh diperbudak, diperulur, atau diperhambakan. Perbudakan, perdagangan budak dan perhambaan, dan segala perbuatan berupa apapun yang tujuan kepada itu dilarang".

Teori badan hukum ini kalau diterapkan untuk membangun dunia pendidikan dengan cara satuan pendidikan dijadikan suatu subyek hukum terdengar cukup relevan dengan harapan bisa mewujudkan cita-cita kelembagaan satuan pendidikan sebagai wahana yang kuat dan berwibawa, sebagaimana dinyatakan dalam UU Sisdiknas. Dengan menjadikannya badan hukum maka penyelenggaraan pendidikan akan didukung oleh suatu organisasi yang memiliki hak-hak seperti manusia, yang tidak mudah diperalat, diperdayai, ataupun diperbudak oleh pihak atau badan hukum lain. Apalagi oleh pihak yang kurang berkepentingan dengan pendidikan.

Hubungan antara penyelenggara pendidikan dan satuan pendidikan yang didirikan selama ini banyak mengindikasikan hubungan yang bersifat subordinatif (bukan koordinatif). Ini artinya satuan pendidikan lebih banyak yang diperlakukan sebagai bawahan. Ada juga yang bahkan diperlakukan laksana obyek hukum dengan kewenangan mengelola sangat minim. Meski ada juga yang walaupun merupakan bawahan tetapi satuan pendidikan merasa sangat terlindungi. Upaya menjadikan satuan pendidikan sebagai badan hukum adalah menjadikannya subyek hukum yang memiliki hak dan kewenangan secara penuh (laksana manusia merdeka).

Latar belakang hubungan itu boleh jadi karena landasan konstitusional Indonesia sebenarnya memberi tugas kepada Pemerintah untuk menyelenggarakan pendidikan. Lalu masyarakat (swasta) diberi pula kewenangan berperan serta menyelenggarakannya. Pemerintah dan swasta dengan demikian adalah "penyelenggara" yang menyelenggarakan pendidikan melalui dibentuknya suatu "satuan pendidikan". Hubungan antara para penyelenggara dengan satuan pendidikan ini merupakan hubungan pemberian otonomi pengelolaan pendidikan. Dalam Penjelasan Pasal 53 UU No 20/2003 tentang Sisdiknas hubungan otonomi ini di tingkat pendidikan dasar dan menengah disebut MBS (manajemen berbasis sekolah) dan di tingkat pendidikan tinggi dikenal otonomi perguruan tinggi. Kemandirian dalam status badan hukum pendidikan bisa dikatakan bertujuan menjamin agar otonomi ini benar-benar ditegakkan.

Otonomi menajemen tidak lain adalah pelimpahan kewenangan dari instansi yang lebih tinggi kepada instansi yang berada di bawahnya. Misalnya berdasarkan UU No 22/2009 tentang Pemerintahan Daerah, desentralisasi bidang pendidikan sesungguhnya dimaknai sebagai pemberian otonomi pengelolaan oleh pusat kepada daerah. Pemerintah daerah dengan demikian adalah penerima otonomi yang diberikan oleh pemerintah pusat, karena pemerintah daerah merupakan bawahan pemerintahan pusat. Peranan swasta yang turut serta menyelenggarakan pendidikan tidak bisa disebut otonomi dari pemerintah, disebabkan karena yayasan (dan yang sejenis) bukan merupakan bawahan dari pemerintah.

Masalah otonomi yang terkait dengan pendidikan menyangkut otonomi bidang akademik, tata organisasi, dan keuangan. Meski demikian, implementasinya di tingkat lapangan sangat bervariasi. Misalnya di perguruan tinggi negeri, ranah otonomi sebelum lahirnya BHMN dianggap tidak menyentuh ranah keuangan. Waktu itu bentuk pengelolaan keuangan berupa PNBP (Penerimaan Negara Bukan Pajak) yang diklaim tidak mencerminkan adanya otonomi, lalu setelah BHMN baru diubah menjadi berciri BLU (Badan Layanan Umum) yang dinilai mulai berbasis otonomi (Perubahan ini berarti, pada mulanya PTN yang tidak menyetorkan dana PNBP ke kas negara bertentangan dengan UU No 20/1997 tentang PNBP, UU No 17/ 2003 tentang Keuangan 
Negara, dan UU No 1/ 2004 tentang Perbendaharaan Negara. PNBP itu antara lain penerimaan dari kegiatan pelayanan yang dapat dilaksanakan kepada masyarakat, seperti pendidikan dan kesehatan. Adapun PP tentang penetapan PTN sebagai BHMN mengatur bahwa penerimaan PTN yang berasal dari masyarakat bukan merupakan PNBP).

\section{Pengalaman penerapan pada BHMN}

Hasil Studi Balitbang tahun 2005 berjudul Penyelenggaraan Perguruan Tinggi Negeri di Era BHMN dalam rangka Otonomi Pendidikan, menunjukkan bahwa pada umumnya PTN yang telah berstatus BHMN merasa mempunyai otonomi penuh dalam aspek pengelolaan keuangan, ketenagaan, penentuan program studi, seleksi mahasiswa, dan mengelola usaha bisnis untuk kepentingan penyelengaraan pendidikan. Keberhasilan PT BHMN dalam aspek penelitian melalui pembentukan kelompok bidang keahlian, dan penelitian diarahkan pada pencarian solusi terhadap permasalahan dan kebutuhan masyarakat serta menjalin kerjasama dengan dunia industri. Reformasi organisasi BHMN dilaksanakan melalui perumusan kebijakan tentang visi, misi, evaluasi (kurikulum dan prodi), standar kelulusan, sistem informasi, program pengembangan, dan pengelolaan keuangan.

Kesulitan penting yang dihadapi oleh PT BHMN menyangkut dua hal: mengubah budaya kerja pegawai negeri (PNS), dan menciptakan unit penghasil dana (income generating units). Untuk itu PTN BHMN menjalin kerjasama yang dilaksanakan oleh Lembaga Penelitian dan Lembaga Pengabdian kepada Masyarakat. Ada persepsi civitas akademika yang menganggap BHMN mengorbitkan kecemasan bagi PNS karena dapat "diberhentikan" jika tidak menenuhi kinerja (etos kerja) yang ditetapkan. Karenanya untuk menjadi BHMN, banyak PTN sudah melakukan penataan internal terlebih dahulu sebelum berstatus BHMN.

Sungguhpun merupakan upaya untuk membebaskan PTN dari belenggu birokrasi pemerintah yang kaku, konvensional dan berbudaya total compliance, $\mathrm{BHMN}$ juga memunculkan beragam tanggapan. Hal itu karena tujuan dibentuknya BHMN telah serta merta dipandang oleh para pengamat sebagai tindakan privatisasi, kapitalisasi, dan komersialisasi PTN. Sofyan Effendi, mantan Rektor UGM, menjelaskan, BHMN bukan economic entity. Dalam perubahan PTN menjadi BHMN tidak ada transfer kepemilikan. Semua lembaga negara yang berstatus BHMN adalah tetap milik Negara yang menerima alokasi anggaran dari APBN. Jadi, kepemilikan BHMN tidak berubah. Seluruh harta kekayaan pemerintah yang ada di PTN, baik tanah, gedung, peralatan, perlengkapan dan SDM, statusnya tetap milik negara. Hanya pengelolaannya didelegasikan oleh Pemerintah kepada suatu Board of Trustees yang mewakili Pemerintah, masyarakat dan masyarakat kampus. Dalam literature Administrasi Negara, lembaga seperti ini disebut independent administrative entity. (Lihat dalam artikel Sofyan Affandi berjudul "Paradigma Salah Tentang PT BHMN", di website Http//sofian.staff.ugm.ac.id/ artikel).

\section{Metode Evaluasi}

Metode yang digunakan dalam mengevaluasi ini dilakukan dengan pendekatan ekploratif kualitatif. Data yang dikumpulkan merupakan data skunder dan primer. Adapun data sekunder diperoleh dari pengumpulan data/dokumen resmi baik yang dikeluarkan oleh pemerintah maupun swasta yang berhubungan dengan otonomi pengelolaan pendidikan dan badan hukum pendidikan. Dokumen dan publikasi tersebut antara lain peraturan perundang-undangan, publikasi resmi dari instansi pemerintah maupun swasta, hasilhasil penelitian terdahulu, informasi terbuka dari media cetak dan media elektronik. Data primer diperoleh dari beberapa cara antara lain dari kesaksian penulis dalam rapat-rapat pembahasan mengenai BHP, rekaman peristiwa pembahasan selama UU BHP disusun, telaah atas amar keputusan Mahkamah Konstitusi, serta penyelenggaraan diskusi fokus dengan para pakar, antara lain Prof.Dr. Arifin Suryaatmaja, Prof. Dr. Bambang Sudibyo, Prof. Dr Soedijarto; Prof Dr Thomas Suyatno; Dr . Edie Toet Hendratno, Romo Karolus Jande, Prof. Dr Sofyan Effendi; Prof. Dr Ing Wardiman Joyonegoro, dan Prof. Dr. Jimly Asshiddiqie.

Sampel penelitian terdiri atas: 1) perguruan tinggi negeri yang sudah dan belum berbentuk badan hukum; dan 2) sekolah negeri yang belum 
berbadan hukum di semua jenjang, dan 2) sekolah swasta yang terdiri atas: penyelenggara (semisal yayasan) dan kepala sekolah formal pada jenjang pendidikan yang terkait.

Penelitian dilakukan sejak pembatalan UU No 9/2009 di tahun 2010 hingga Maret 2011. Bertempat di Jakarta dan di beberapa daerah yang menjadi obyek pencarian informasi seputar permasalahan BHP.

\section{Hasil Studi Evaluasi}

Hasil studi menunjukkan bahwa secara umum para pelaksana pendidikan di tingkat satuan pendidikan membutuhkan ruang berkembang secara memadai. Dalam hubungannya dengan pihak penyelenggara, semacam yayasan pada pendidikan swasta, ataupun dengan Pemerintah dan pemerintah daerah di lingkup sekolah negeri, satuan pendidikan cukup banyak yang merasa terbantu. Misalnya satuan pendidikan yang didonasi oleh yayasan, atau di sekolah negeri yang pendanaannya berasal dari negara. Beberapa ada yang bahkan diperlakukan seperti lembaga mandiri, seperti BHMN dan beberapa lembaga swasta.

Hubungan antara pengelola dan penyelenggara ini dikenal dalam UU Sisdiknas No 20/ 2003 sebagai hubungan berlandaskan pemberian otonomi. Komunitas swasta ada yang lebih senang menyebut hubungan ini hubungan koordinatif. Ruang kemandirian yang memadai bagi perkembangan satuan pendidikan sesungguhnya merupakan suatu keniscayaan (dengan sendirinya harus ada), sebab tanpa otonomi, satuan pendidikan dipastikan bakal sulit berkembang.

Para pengelola satuan pendidikan tidak memiliki penterjemahan seragam terhadap apa yang sesungguhnya dimaksud dengan MBS maupun otonomi perguruan tinggi. Hal demikian karena kebutuhan masing-masing pengelola satuan pendidikan berbeda dan bervariasi, dipengaruhi oleh ciri, kondisi, dan pola manajemen yang dikembangkan oleh masing-masing satuan pendidikan. Ada yayasan yang mendanai satuan pendidikannya secara penuh sehingga satuan pendidikan tidak perlu memikirkan bagaimana mencari dana sendiri. Namun ada juga yang memberikan otonomi penuh kepada satuan pendidikan termasuk dalam hal mencari dan mengelola keuangan. Ada pula yang di tengah dua pola ini, yakni yayasan mendanai, namun memberi kesempatan yayasan mencari dana sambil menerapkan aturan-aturan yang ketat. Kecenderungan realitas dunia pendidikan bahkan menunjukkan bahwa PTS saat ini sudah dikelola secara otonom sedangkan PTN belum, yang disebabkan karena sistem pengelolaan keuangan masih menggunakan PNBP.

Dengan fenomena beragam di atas, ketentuan dalam UU BHP No 9/2009 yang menyamakan kewajiban satuan pendidikan di semua jenjang, baik negeri maupun swasta, berbentuk BHP, termasuk soal kewajiban memisahkan kekayaan satuan pendidikan dari kekayaan penyelenggara, dinilai tidak cocok dengan ciri dan karakter yang sudah lama mapan di masing-masing lembaga. Terbukti juga bahwa tidak semua satuan pendidikan setuju dikatakan diperbudak oleh badan hukum lain yang menyelenggarakannya. Pemisahan kekayaan negara dalam satuan pendidikan negeri juga merupakan pengecualian dari UU No 17/ 2003 tentang Keuangan Negara, di mana kekayaan negara yang dipisahkan sebenarnya masih tetap merupakan kekayaan negara.

Semula, ketentuan dalam UU No 9 Tentang BHP sebenarnya dapat dipahami sebagai upaya memperjelas konsep MBS dan otonomi perguruan tinggi. Dalam UU ini persoalan terkonsentrasi pada: 1) Kekayaan pendiri harus dipisahkan dari kekayaan satuan pendidikan; 2) Tatakelola organisasi harus memberikan peluang lebih besar bagi satuan pendidikan untuk berkembang. Sayangnya, penyelenggara pendidikan pada umumnya sudah memiliki aturan yang unik dan berciri kebutuhan masing-masing. Atas dasar ini, otonomi ala BHP lalu diakui merubah tradisi Muhamadiyah yang berdiri sejak 1912, Taman Siswa 1922, dan Katolik sejak abad 15, juga ciri pendidikan lain di tanah air. Jarang sekali di antara mereka ini yang begitu saja menyetujui dipisahkan kekayaannya. Ini semua memberikan kesimpulan bahwa kebutuhan satuan maupun penyelenggara pendidikan ternyata tidak sama. Cukup banyak yang berpandangan bahwa BHP sebenarnya hanya cocok untuk sekelompok satuan pendidikan. Lebih tepatnya, hanya cocok untuk perguruan tinggi negeri yang memiliki persoalan 
anggaran sistem PNBP, karena aturan PNBP dinilai sangat menghambat kreatifitas PTN, terutama yang bersinggungan dengan dana pungutan masyarakat.

Ada yang menilai, satuan pendidikan dijadikan badan hukum atau tidak, sebenarnya bukan permasalahan pokok. Hal yang lebih penting, persoalan pendanaan pendidikan di negeri ini yang sudah saatnya diperbaiki. Misalnya soal pembiayaan yang sebagian menilai, bahwa konstitusi kita menghendaki pembiayaan pendidikan seharusnya ditanggung seluruhnya oleh negara. Untuk yang berstatus negeri, sistem pemberlakuan semacam BLU lebih baik. Jika pendidikan bisa berjalan dengan pembenahan pada masalah-masalah ini maka soal BHP atau tidak bukan menjadi masalah besar.

Tetapi ide satuan pendidikan sebagai badan hukum sebenarnya juga dibuat dalam rangka memberikan solusi bagi pendanaan pendidikan. Masalah pemisahan kekayaan merupakan core masalah badan hukum yang diyakini dapat memberikan keleluasaan bagi satuan pendidikan untuk berkembang secara optimal. BHMN sudah mempraktikkan ketentuan ini dan dinilai punya andil positif dalam memajukan perguruan tinggi. Dengan mengecualikan ekses melambungnya SPP pada BHMN, UU BHP sesungguhnya telah mengantisipasinya dengan membatasinya maksimal $1 /$ 3 dari dana opersional satuan pendidikan. Tetapi sebagian orang menilai UU BHP tetap dirasakan kebablasan karena mengandung makna pelepasan tanggung jawab oleh negara terhadap kewajiban membiayai pendidikan. Kekhawatiran melangitnya biaya SPP seperti dalam kasus BHMN yang memicu bangkitnya tuduhan neo-liberalism tetap sulit disembunyikan.

Pasal 53 UU No 20 pada dasarnya memberikan pilihan, bahwa yang wajib menjadi badan hukum adalah penyelenggaranya, atau satuan pendidikannya, atau kedua-duanya. Kalau demikian maka sesungguhnya banyak sekali penyelenggaraan pendidikan sudah berbentuk BHP. Hal ini karena yayasan, badan wakaf dan semacamnya sudah merupakan badan hukum. Tetapi UU 9/2009 mewajibkan satuan pendidikannya yang wajib menjadi BHP. Inilah yang kemudian menimbulkan pendapat pro dan kontra. Jika UU Yayasan (UU 16/ 2001 jo. UU 28/ 2004, PP 63/
2008) dinilai bermasalah, sebaiknya UU tersebut yang perlu direvisi bukan membuat UU baru. Saat ini puluhan ribu yayasan penyelenggara pendidikan, khususnya pendidikan dasar dan pendidikan menengah, juga belum seluruhnya menyesuaikan dengan UU Yayasan. Jalan keluar yang lain: Universitas eks BHMN diberikan payung baru berupa BHP (yang baru). Adapun yang sudah ikut badan hukum penyelenggara tidak perlu dipermasalahkan. Di luar itu, masyarakat boleh memilih antara badan hukum atau tidak (seperti bentuk aslinya).

Pendapat yang menilai badan hukum pendidikan bukan merupakan inti masalah pendidikan di Indonesia memandang bahwa Pendidikan nasional perlu difokuskan pada pembangunan manusia seutuhnya, bukan pada pembangunan ekonomi (economic development). Jangan menyamakan pengelolaan pendidikan sebagai pengelolaan usaha, seperti dalam upaya menswastakan pendidikan negeri. Pendidikan nasional seyogyanya mengakomodasi prinsip etatis, paternalistik dan kebhinekaan, sehingga memberi kesempatan bagi penyelenggara dan pengelola pendidikan untuk mencoba dan mencari berbagai alternatif guna mendapatkan pilihan terbaik demi peningkatan mutu pendidikan. Selain itu juga perlu mengacu pada best practice pendidikan di negara-negara maju yang telah terbukti menghasilkan pendidikan bermutu tinggi.

Untuk semua itu, Pemerintah perlu membiayai secara penuh pendidikan negeri pada pendidikan dasar, dan untuk swasta pemerintah berkewajiban mensubsidi. Badan hukum pendidikan jangan sampai mengurangi tanggung jawab pemerintah, dan tidak mengurangi pelaksanaan Tri Darma perguruan tinggi. Hak-hak historis dan konstitusional penyelenggara pendidikan seperti yayasan, dalam hal menyelenggarakan pendidikan secara langsung, harus tetap dipertahankan. Keberagaman dalam bentuk badan hukum dan tata kelola harus tetap dipertahankan atau justru perlu dikembangkan karena merupakan aset dan potensi bangsa.

Agar satuan pendidikan bisa lebih bertanggungjawab, bisa juga diperlakukan aturan perseroan terbatas yang bersifat terbuka dan tertutup. Yakni penyelenggara tidak perlu mengurusi hingga ke dalam perusahaan. Ada AD/ 
ART yang bisa digunakna sehingga bila ada pelanggaran mudah ditindak. Ini artinya, hal-hal yang sudah diatur dengan peraturan sendiri, tidak perlu diatur kembali dalam RUU badan hukum pendidikan baru, kalaulah akan disusun.

\section{Simpulan dan Saran Simpulan}

Para penyelanggara dan pengelola satuan pendidikan terbelah menjadi dua pendapat besar, yakni yang menganggap badan hukum merupakan pilihan ideal bagi semua bentuk satuan pendidikan, dan kelompok lain menilai bahwa badan hukum baik untuk beberapa jenis satuan pendidikan namun tidak diperlukan untuk jenis pendidikan lainnya. Amanat UU No 20 Pasal 53 tidak dibatalkan. Isinya mewajibkan penyelenggara dan/atau satuan pendidikan berbentuk badan hukum pendidikan. Ini berarti bahwa undang-undang tentang badan hukum untuk satuan atau penyelenggara pendidikan, walaupun berlaku untuk sebagian, terbuka kemung- kinan untuk disusun kembali agar kebutuhan untuk itu dapat dilayani oleh dunia hukum Indonesia.

\section{Saran}

Semua pihak perlu merenungkan persoalan yang lebih besar di balik terbitnya keputusan MK serta berbagai kelemahan yang tedapat dalam UU No 9. Perlu dipertimbangkan apakah benar bahwa status badan hukum layak diberlakukan bagi PTN eks BHMN saja, sehingga PTS mengacu kembali pada ketentuan perundang-undangan yang sudah ada yakni: UU Yayasan, UU Wakaf, dan UU lain seperti UU Perkumpulan. Putusan MK pada tanggal 30/3/2010 berisi berbagai rambu-rambu, terutama terkait hak kebebasan berserikat dan berkumpul yang dijamin UUD. Karenanya peraturan tentang badan hukum pendidikan baru tidak perlu lagi memaksakan penyeragaman. UU badan hukum pendidikan cukup memberikan "peluang otonomi" bagi satuan pendidikan.

\section{Pustaka Acuan}

Badan Penelitian dan Pengembangan. 2005. Penyelenggaraan Perguruan Tinggi Negeri di Era BHMN dalam Rangka Otonomi Pendidikan.

Chidir Ali, 1999. Badan Hukum. Penerbit PT Alumni, Bandung, Cetakan kedua.

Departemen Pendidikan Nasional, 2003, Undang-Undang Nomor 20 Tahun 2003 Tentang Sistem Pendidikan Nasional.

Departemen Pendidikan Nasional, 2009, Undang-Undang Nomor 9 Tahun 2009 Tentang Badan Hukum Pendidikan.

Http//sofian.staff.ugm.ac.id/artikel. Diunduh tanggal 15 April 2011.

Keputusan Mahkamah Konstitusi. No. 021/PUU-IV/2006 tgl 22/2/2007 halaman 134-135 yang dikutip kembali dalam putusan no11-14-21-126-136/PUU-VII2009 tgl 30/3/2010 tgl 30/3/2010 butir 3.24 .

Marwan, M.. dan Jimmy P., 2009. Kamus Hukum, Cetakan pertama, Reality Publisher, Surabaya.

R. Subekti, 1979. Aneka Perjanjian, Cetakan IV, Penerbit PT. Intermasa: Jakarta

Undang-Undang Sementara-RI Tahun 1950 (UUD RIS, 1950)

Undang-Undang Dasar RI Tahun 1945 dan Amandemen.

Undang-Undang RI Nomor 22/2009 tentang Pemerintahan Daerah.

Undang-Undang RI Nomor 17/ 2003 tentang Keuangan Negara.

Undang-Undang RI Nomor 16/ 2001 Tentang Yayasan.

Undang-Undang RI Nomor 1/2004 tentang Perbendaharaan Negara.

Undang-Undang RI Nomor 20/1997 tentang Penerimaan Negara Bukan Pajak (PNBP). 